\title{
Anatomy of Herpes Simplex Virus DNA
}

\section{Apparent Exclusion of Some Parental DNA Arrangements in the Generation of Intertypic (HSV-1 $\times$ HSV-2) Recombinants $\dagger$}

\author{
LAWRENCE S. MORSE, ${ }^{1}$ TIMOTHY G. BUCHMAN ${ }^{1}$ BERNARD \\ ROIZMAN, ${ }^{1 *}$ AND PRISCILLA A. SCHAFFER ${ }^{2}$ \\ Marjorie B. Kovler Viral Oncology Laboratories, University of Chicago, Chicago, Illinois 60637, ${ }^{1}$ and Sidney \\ Farber Cancer Institute, Harvard Medical School, Boston, Massachusetts 02115
}

Received for publication 22 April 1977

\begin{abstract}
We are reporting the physical location of parental DNA sequences in 28 recombinants produced by crossing herpes simplex viruses (HSV) 1 and 2. The parental crosses were of two kinds. In the first, temperature-sensitive mutants of HSV-1 and HSV-2 were crossed to produce wild-type recombinants. In the second, temperature-sensitive mutants of HSV-1 rendered resistant to phosphonoacetic acid were crossed with wild-type HSV-2, and recombinants that multiplied at nonpermissive temperature and were resistant to the drug were selected. The DNAs of the recombinants were mapped with XbaI, EcoRI, $H p a \mathrm{I}$, $H s u I$, BglII, and, in some instances, $K p n I$ restriction endonucleases. The results were as follows. (i) We established the colinear arrangements of HSV-1 and HSV-2 DNAs. (ii) There was extensive interchange of genomic regions, ranging from the exchange or the entire L of S component of HSV DNA to substitutions of regions within the same component. In some recombinants, the reiterated sequences $a b$ and $a c$ bracketing the $\mathrm{L}$ and S components of HSV DNA were heterotypic. Most recombinants grew well and showed no obvious defects. (iii) The number of crossover events ranged from one to as many as six. Although crossover events occurred throughout the DNA, some clustering of crossover events was observed. (iv) Analysis of recombinants permitted localization of several markers used in this study and appears to be a useful technique for marker mapping. (v) As previously reported, HSV DNA consists of four populations, differing in relative orientation of the $\mathrm{L}$ and $\mathrm{S}$ components. All recombinants could be displayed in one arrangement of $L$ and $S$ such that the number of crossover events was minimized. The data are consistent with the hypothesis that only one arrangement of the parental DNA participates in the generation of recombinants.
\end{abstract}

In this paper we report on the DNA structure and properties of recombinants produced between herpes simplex viruses (human herpesvirus, HSV) 1 and 2. Pertinent to the design and purpose of these studies are the following.

(i) The size of HSV-1 DNA has been shown to be $95 \times 10^{6}$ to $100 \times 10^{6}$ in molecular weight, as determined from measurements of contour length $(2,11,39)$, sequence complexity (10), sedimentation velocity in sucrose gradients relative to that of T4 phage DNA (20), and summation of the size of restriction endonuclease fragments $(13,14)$. Although HSV-2 DNA cosediments with HSV-1 DNA, summation of the molecular weights of restriction endonuclease fragments suggests that it may be larger than HSV-1 DNA by $3 \times 10^{6}$ (G. S. Hayward, T.

$\dagger$ Dedicated to the memory of Maurizio Terni.
Buchman, and B. Roizman, manuscript in preparation).

(ii) HSV-1 DNA consists of two covalently linked components, $\mathrm{L}$ and $\mathrm{S}$, each consisting of unique sequences $U_{L}$ and $U_{S}$ bracketed by inverted repeats (34). Measurements in our laboratory showed that the $\mathrm{L}$ and $\mathrm{S}$ components comprise 82 and $18 \%$ of the DNA, respectively, and that the inverted repeats bracketing the $\mathrm{L}$ component, designated $a b$ and $b^{\prime} a^{\prime}$, each contain $6 \%$ of total DNA, whereas the inverted repeats of the $\mathrm{S}$ component, designated $a^{\prime} c^{\prime}$ and $c a$, each contain $4.3 \%$ of total DNA $(28,29,39)$. The sequence of regions identified in these measurements is $a b U_{L} b^{\prime} a^{\prime} a^{\prime} c^{\prime} U_{S} c a$. These measurements have since been confirmed (7). Sequence $a$ common to both $\mathrm{L}$ and S components is arranged in tandem, as evidenced by the fact that HSV-1 DNA circularizes after 
digestion with a processive exonuclease $(11,34$, 38). Measurements of the $a$ sequence suggest that it is 400 to 600 base pairs in length and that it contains a sequence $d$ and its inverted repeat, $d^{\prime}(16,38)$. Restriction endonculease analyses of HSV-2 DNA suggest that it has a similar structure (Hayward et al., manuscript in preparation).

(iii) On the basis of the observation that the terminal regions of the $\mathrm{L}$ and $\mathrm{S}$ components are repeated internally, Sheldrick and Berthelot (34) suggested that L and S components could, through legitimate recombination, invert relative to each other. Data reported from this laboratory and based on partial denaturation profiles, identification of the termini of the DNA, and restriction endonuclease analyses indicated that HSV-1 DNA consists of equimolar concentrations of four populations of DNA molecules, differing solely in the relative orientation of $\mathrm{L}$ and $\mathrm{S}$ components $(14,28,29)$. These data have since been confirmed $(6,7,35,40,42)$. Restriction endonuclease studies of HSV-2 DNA show that it, too, consists of four populations differing in the arrangement of $\mathrm{L}$ and $\mathrm{S}$ components. In our studies the four populations have been designated $\mathrm{P}$ (arbitrary prototype), $I_{L}$ (inversion of $L$ component), $I_{S}$ (inversion of $S$ component), and $\mathrm{I}_{\mathrm{SL}}$ (inversion of both $\mathrm{S}$ and $\mathrm{L}$ components). One consequence of this arrangement of HSV DNA pertinent to this study is that restriction endonucleases that do not cleave within the reiterated regions generate three fragment classes. The first class, corresponding in concentration to the molarity of intact DNA, comprises fragments mapping between the first and last cleavage within the $U_{L}$ and $U_{S}$ regions, respectively. The second class comprises the four terminal fragments, each present in $0.5 \mathrm{M}$ concentration relative to the molarity of the intact DNA. The third class comprises $0.25 \mathrm{M}$ fragments, which arise through the joining of the $0.5 \mathrm{M} \mathrm{L}$ and S terminal fragments across the $b^{\prime} a^{\prime} a^{\prime} c^{\prime}$ junction in consequence of inversions of $\mathrm{L}$ and $\mathrm{S}$ components.

(iv) The purpose of these studies was twofold. The first was to take advantage of the lack of correspondence of HSV-1 and HSV-2 restriction endonuclease cleavage sites and of the differences in the electrophoretic mobilities of HSV1- and HSV-2-specific polypeptides to map the location of templates specifying the polypeptides by analyzing HSV-1 $\times$ HSV-2 recombinants. This technique was used in an elegant fashion to map adenovirus $t s$ mutations and the location of templates specifying polypeptides on the physical map of the DNA $(12,23)$. The second objective was to determine whether all four arrangements of HSV DNA participate in the generation of recombinants. The formation of recombinants was predicted by the observation that HSV-1 and HSV-2 DNA show at least $47 \%$ homology, with good matching of base pairs $(4,19)$. HSV-1 and HSV-2 ts mutants have been shown to complement each other efficiently, and, in fact, formation of HSV-1 $\times$ HSV-2 recombinants has been reported (8). In this paper we are reporting the DNA sequence arrangements and some phenotypic properties of recombinants obtained in four series of HSV$1 \times$ HSV-2 crosses. The location of the templates specifying viral polypeptides will be communicated in a subsequent paper.

\section{MATERIALS AND METHODS}

Virus and cells. The virus strains used in this study were (i) HSV-1(KOS ts 66 ), a DNA ${ }^{+}$ts mutant described elsewhere (1, 3, 32, 33); (ii) HSV-1(17 tsJ), a $\mathrm{DNA}^{-}$ts mutant (kindly provided by J. SubakSharpe) whose properties have been described (22, 37); (iii) HSV-1(HFEM $t s \mathrm{~N}_{102}$ ), a $\mathrm{DNA}^{-}$mutant kindly provided by A. Buchan; (iv) HSV-2(186 ts B5), a $\mathrm{DNA}^{-} t s$ mutant described elsewhere $(3,26,32)$; (v) HSV-2(186), the parent strain of HSV-2(186 ts B5); and (vi) HSV-2(GP6), a syn ${ }^{-}$mutant obtained by Cassai et al. (5) from HSV-2(G) and kindly furnished to us by $M$. Terni. Virus stocks were prepared from plaque-purified seed by passage at low multiplicity $(0.01 \mathrm{PFU} /$ cell $)$ in Vero cells at $33.5^{\circ} \mathrm{C}$. The Vero and HEp-2 cells were originally obtained from Flow Laboratories, Inc., Rockville, Md., and subsequently propagated at the University of Chicago. The procedure for titering stocks by the liquid overlay plaque assay technique has been described previously (31).

Construction of PAA ${ }^{r}$ mutants. Phosphonoacetic acid (PAA) $(21,25)$ was a gift of Abbott Laboratories, North Chicago, Ill. HSV-1(17 tsJ) and HSV1(HFEM $t s \mathrm{~N} 102$ ) were made resistant to PAA $\left(\mathrm{PAA}^{\mathrm{r}}\right)$ by propagation in the presence of gradually increasing concentrations of the drug. Three cycles of plaque purification, each interspersed by five passages at low multiplicity in Vero cells, resulted in the selection of genetically stable mutants resistant to $100 \mu \mathrm{g}$ of PAA per ml of medium. Resistant virus was plaque-purified under selective conditions, using an agarose overlay ( $0.5 \%$ agarose in mixture 199 supplemented with $1 \%$ calf serum), as described for selection of recombinants. The $t s$ mutants rendered $\mathrm{PAA}^{\mathrm{r}}$ by this procedure retained their $t s$ phenotype throughout the serial passages.

Genetic crosses. Two basic selection schemes were used to obtain intertypic recombinants. The first involved infection with ts mutants of HSV-1 and HSV-2 and selection for progeny capable of growing at nonpermissive $\left(t s^{+}\right)$temperatures (8), The second entailed selection of $t s^{+} \mathrm{PAA}^{\mathrm{r}}$ progeny from cells doubly infected with a wild-type HSV-2 and an HSV-1 $t s^{-}$PAA $^{r}$ mutant. In this procedure, Vero cells were infected at a multiplicity of 3 PFU/ cell with each of the HSV serotypes. After adsorp- 
tion for $2 \mathrm{~h}$, the inoculum was aspirated, and the cells were overlaid with medium 199-1 (mixture 199 supplemented with $1 \%$ calf serum) and incubated at $33.5^{\circ} \mathrm{C}$ for 18 to $20 \mathrm{~h}$. For preparation of virus stocks, the contents of the flask were frozen and thawed three times and subjected to sonic treatment for $30 \mathrm{~s}$. Titrations were done at 33.5 and $38.5^{\circ} \mathrm{C}$ under a liquid overlay (31) in the presence and in the absence of $100 \mu \mathrm{g}$ of PAA per ml of medium. Virus dilutions that would yield approximately 1 to 10 PFU per dish were then plated under agarose overlay containing PAA and incubated at $38.5^{\circ} \mathrm{C}$ for 2 to 3 days. For plaque purifications, the contents of individual plaques were harvested, diluted in a mixture of $50 \%$ medium $199-1$ and $50 \%$ skim milk, and subjected to sonic treatment. This stock was then plated and plaque-purified two to six more times. Final stocks were made by propagation at low multiplicity at $33.5^{\circ} \mathrm{C}$.

Labeling of viral DNA. For labeling viral DNA with ${ }^{32} \mathrm{P}$, Vero cell flask cultures were treated as follows. First, the cultures were incubated at $33.5^{\circ} \mathrm{C}$ for 8 to $10 \mathrm{~h}$ in a mixture of 1 part Eagle minimum essential medium free of phosphate and supplemented with $1 \%$ calf serum dialyzed against lowphosphate buffer to 2 parts phosphate-free minimum essential medium supplemented with $1 \%$ inactivated calf serum. Next, the cell cultures were washed, replenished with phosphate-free minimum essential medium containing $1 \%$ inactivated calf serum, and reincubated for an additional 6 to $8 \mathrm{~h}$. Finally, the cell cultures were infected with recombinant or parental virus at a multiplicity of approximately 5 and adsorbed for $2 \mathrm{~h}$. At the end of the adsorption interval, the inoculum was aspirated and the cells were incubated at $33.5^{\circ} \mathrm{C}$ in phosphate-free mimimum essential medium containing $1 \%$ inactivated fetal calf serum and $60 \mu \mathrm{Ci}$ of ${ }^{32} \mathrm{P}$ (New England Nuclear, Boston, Mass.) per ml for 24 to $30 \mathrm{~h}$.

Purification of viral DNA. The contents of the ${ }^{32} \mathrm{P}$-labeled cultures were frozen and thawed three times, poured into a $13-\mathrm{ml}$ Corex tube, and centrifuged at $8,000 \mathrm{rpm}$ in a Sorvall RC2B centrifuge. Polyethylene glycol (average molecular weight, 6,000 ) and $\mathrm{NaCl}$ were then added to the supernatant fluid to a final concentration of $10 \%$ and $0.5 \mathrm{M}$, respectively. The mixture was stored in wet ice for $30 \mathrm{~min}$ and then centrifuged at $4^{\circ} \mathrm{C}$ and 15,000 rpm for $20 \mathrm{~min}$ in the Sorvall RC2B centrifuge. The pellet was suspended in $1.0 \mathrm{ml}$ of $0.01 \mathrm{M}$ Tris- $0.050 \mathrm{M}$ EDTA, pH 7.5, and subjected to sonic treatment for $20 \mathrm{~s}$. Sodium dodecyl sulfate and Sarkosyl (ICN, K \& $\mathrm{K}$ Laboratories, Inc., Cleveland, Ohio), in final concentrations of $0.5 \%$ and $1 \%$, respectively, were added. The DNA was then extracted once with phenol and precipitated at $0^{\circ} \mathrm{C}$ with 3 volumes of ethanol in the presence of $0.3 \mathrm{M}$ sodium acetate. The precipitate was collected by centrifugation, suspended in TE buffer (consisting of $0.01 \mathrm{M}$ Tris and $0.001 \mathrm{M}$ EDTA, pH 7.5), and dialyzed first against TE containing $0.2 \mathrm{M} \mathrm{NaCl}$ and then extensively against TE buffer.

Restriction endonucleases. Restriction endonucleases are designated according the nonmenclature of Smith and Nathans (36). EcoRI, BglII, HpaI, $H s u I$, and $X b a I$ were prepared from appropriate cell pastes by standard purification procedures: precipitation of DNA (streptomycin sulfate), fractionation of protein (ammonium sulfate), molecular sieve chromatography (agarose beads), and ion exchange chromatography (phosphocellulose). KpnI was obtained from New England Biolabs, Waverly, Mass. All restriction endonuclease preparations were shown to be free of contaminating exo- or endonuclease activity before use.

Restriction endonuclease digestion. The DNA was cleaved with restriction endonucleases by incubation for $2 \mathrm{~h}$ at $37^{\circ} \mathrm{C}$ in a total volume of 100 to 200 $\mu l$. For digestion with $\mathrm{HsuI}$ or $\mathrm{HpaI}$ the mixtures contained $20 \mathrm{mM}$ Tris (pH 7.5), $20 \mathrm{mM} \mathrm{MgCl}_{2}$, and 20 $\mathrm{mM} \mathrm{NaCl}$. For digestion with $\mathrm{BglII}$ or $\mathrm{XbaI}$ the mixtures contained $20 \mathrm{mM}$ Tris (pH 7.5), $10 \mathrm{mM}$ $\mathrm{MgCl}_{2}$, and $10 \mathrm{mM} \mathrm{NaCl}$. For digestion with EcoRI the mixtures contained $30 \mathrm{mM}$ Tris ( $\mathrm{pH} 7.5$ ), $20 \mathrm{mM}$ $\mathrm{MgCl}_{2}$, and $30 \mathrm{mM} \mathrm{NaCl}$. The reaction was stopped by the addition of $60 \mathrm{mM}$ EDTA. Sucrose ( $20 \mu \mathrm{l}, 60 \%$ [wt/wt]) containing bromophenol blue was also added to the reaction mixture at this time.

Agarose gel electrophoresis. The DNA fragments in the limit digests were separated by electrophoresis through tubes ( 1 by $20 \mathrm{~cm}$ ) containing $0.4 \%$ agarose (Seakem, Marine Colloids, Inc., Rockland, Md.) for $18 \mathrm{~h}$ at $2.25 \mathrm{~V} / \mathrm{cm}$ in Tris-phosphate buffer (30 $\mathrm{mM} \mathrm{NaH} \mathrm{PO}_{4}, 36 \mathrm{mM}$ Tris, $1.0 \mathrm{mM}$ EDTA, pH 8.0) $(13,14)$. After electrophoresis, the gels were sliced longitudinally and dried on Whatman No. 1 filter paper. The autoradiograms were made on Cronex Medical X-ray film.

Designation of restriction endonuclease fragments. Designation of the restriction endonuclease fragments follows the agreement reached at the Third Herpesvirus Workshop, Cold Spring Harbor, September 1976, and differs from that published previously by this laboratory $(9,13,14)$. The problem that the revised nomenclature is designed to solve arises from the fact that HSV DNA contains four populations differing in the relative orientation of the $\mathrm{L}$ and $\mathrm{S}$ components. Consequently, a restriction endonuclease digest of HSV DNA contains, in addition to four $0.5 \mathrm{M}$ terminal fragments (two each from $\mathrm{L}$ and $\mathrm{S}$ termini), four $0.25 \mathrm{M}$ fragments arising from the joining of the $L$ and $S$ terminal fragments and containing, therefore, in various permutations, the sequences present in the $0.5 \mathrm{M}$ terminal fragments. As illustrated in the KpnI map of HSV-2 DNA (Fig. 1), the four $0.5 \mathrm{M}$ terminal fragments are $H, D, T_{1}$, and $T_{2}$. The same sequences are also present in the $0.25 \mathrm{M}$ fragments spanning the junction of $\mathrm{L}$ and $\mathrm{S}$ components. Thus, the $0.25 \mathrm{M}$ fragment arising from digestion of the DNA in the $P$ arrangement contains sequences of the $D$ and $T_{1}$ fragments. The $\mathrm{D}$ fragment, for example, is generated by the cleavage of the DNA in the $I_{L}$ and $I_{S L}$ arrangement, etc. The system of designation permits naming of all fragments by single letters according to descending size (A, B, etc.) or by double letters describing the component parts. Thus the $0.25 \mathrm{M}$ fragment can be denoted either as fragment $B$ or as fragment $\mathrm{DT}_{1}$. Similarly, for the $0.25 \mathrm{M}$ fragments in the $I_{S}, I_{L}$, and $\mathrm{I}_{\mathrm{SL}}$ arrangements, the designations are $\mathrm{C}$ or $\mathrm{DT}_{2}, \mathrm{~F}$ or $\mathrm{HT}_{1}$, and $\mathrm{G}$ or $\mathrm{HT}_{2}$, respectively. We have chosen to present all $0.25 \mathrm{M}$ fragments by the double-letter 


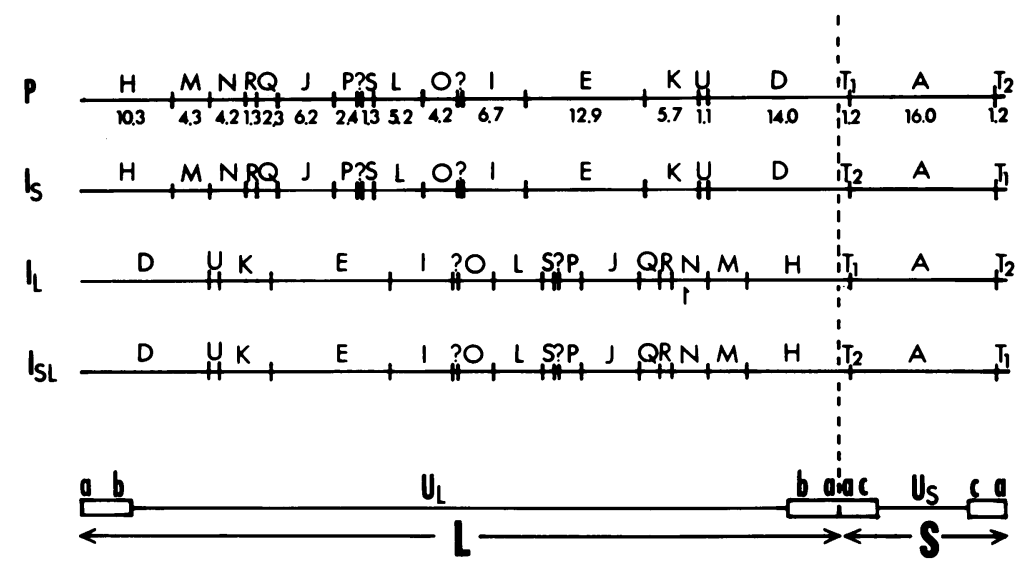

Fig. 1. KpnI restriction endonuclease map of HSV-2 DNA shown in all four arrangements arising as a consequence of inversion of the $L$ and $S$ components relative to each other. $P$-prototype arrangement, $I_{L}-$ inversion of $L$ component, $I_{S}-$ inversion of $S$ component, and $I_{S L}$-inversion of both $L$ and $S$ components. The $P$ arrangement shown is colinear with other restriction endonuclease maps, shown in Fig. 3, 5, and 7 . Data from Hayward et al. (manuscript in preparation).

designations. It should also be noted that enzymes that cleave within the reiterated sequence generate terminal fragments identical in size that comigrate. Thus, $K p n$ I cleaves within the $a c$ sequence and generates two $\mathrm{T}$ fragments that comigrate. Because of the possibility of microheterogeneity in these fragments, we have chosen to designate them $T_{1}$ and $T_{2}$, in the order of their appearance in the prototype molecules. In addition to $K p n I$, enzymes that cut within reiterated regions are EcoRI (HSV-1 ac sequence) and $\mathrm{HpaI}$ (HSV-1 $a b$ sequence). All representations of the DNA in subsequent figures of this paper show only one arrangement of HSV DNA, selected as the prototype arrangement. All other arrangements can be easily generated by inverting $\mathrm{L}, \mathrm{S}$, or both $\mathrm{L}$ and $\mathrm{S}$ components.

\section{RESULTS}

Selection and biological properties of recombinants: construction of intertypic recombinants. The four series of intertypic recombinants analyzed in these studies were prepared by infecting cells with selected strains of HSV-1 and HSV-2 containing the markers shown in Table 1 . The doubly infected Vero cells were incubated at $33.5^{\circ} \mathrm{C}$ for 18 to $20 \mathrm{~h}$. The progeny was then plated under agarose overlay and incubated at nonpermissive temperature $\left(38.5^{\circ} \mathrm{C}\right)$. The progenies of series $\mathrm{A}, \mathrm{B}$, and $\mathrm{C}$ were plated under overlay containing PAA (100 $\mu \mathrm{g} / \mathrm{ml})$.

The $\mathrm{A}, \mathrm{B}$, and $\mathrm{C}$ series were prepared by crossing an HSV-1 $t s$ parent made PAA ${ }^{\mathrm{r}}$ with $t s^{+}$strains of HSV-2. Thus, in all instances the progenies were selected for $t s^{+} \mathrm{PAA}^{\mathrm{r}}$. The selected progeny was then analyzed for expression of the syn marker. In series A, the HSV-2 strain expressed syncytial plaque morphology $\left(\right.$ syn $\left.^{-}\right)$, whereas in series B and C, the HSV-2 strain was nonsyncytial $\left(s y n^{+}\right)$. All crosses in series $\mathrm{A}, \mathrm{B}$, and $\mathrm{C}$ were done at a multiplicity of 3 PFU/cell of each parent. In preliminary experiments we analyzed the effect of multiplicity on the production of virus capable of growing under the selective conditions. In these experiments the progeny of the cross was titered under a liquid overlay. We observed that the fraction of total yield represented by the selected progeny decreased when the ratio of HSV-1 to HSV-2 multiplicities was greater than 1 and remained relatively constant at ratios ranging from 1 to 0.25 . The $\mathrm{D}$ series was prepared by crossing $t s$ parents and selecting for the ability of the progeny to grow at nonpermissive temperature as previously reported by Esparza et al. (8).

Recombinants were isolated by picking plaques from infected monolayers overlaid with agarose and incubated under selective conditions. In series A, B, and C, plaque isolates of the initial cross were plaque-purified repeatedly under selective conditions before stocks were prepared. In preliminary experiments we observed that approximately 0.5 to as much as $3 \%$ of the progeny of doubly infected cells plated under selective conditions. However, the progeny of many of the isolated plaques segregated upon further passage into parental types or a parental type and recombinants. Some segregants were readily demonstrable upon cultivation of progenies of individual plaques under selective and nonselective conditions. Other segregants were identified by analyses of the plaque morphology in HEp-2 cells. In some instances, the presence of parental and recombinant progeny became manifest only after digestion with endonucleases in that 
TABLE 1. Phenotype and biological properties of parental strains and intertypic recombinants ${ }^{a}$

\begin{tabular}{|c|c|c|c|c|c|c|}
\hline \multirow{2}{*}{ Series } & \multicolumn{2}{|c|}{ Parental strains and phenotypes } & \multirow{2}{*}{$\begin{array}{l}\text { Recombi- } \\
\text { nant pheno- } \\
\text { type selected }\end{array}$} & \multirow{2}{*}{$\begin{array}{l}\text { Recombi- } \\
\text { nant desig- } \\
\text { nation }\end{array}$} & \multirow{2}{*}{$\begin{array}{l}\text { Plaque mor- } \\
\text { phology in } \\
\text { vero cells }\end{array}$} & \multirow{2}{*}{$\begin{array}{c}\text { Efficiency } \\
\text { of platin } \\
38.5^{\circ} \mathrm{C} / \\
33.5^{\circ} \mathrm{C} \text { ) }\end{array}$} \\
\hline & HSV-1 & HSV-2 & & & & \\
\hline A & $\begin{array}{l}17 t s \mathrm{~J} \\
\quad\left(t s^{-} \mathrm{PAA}^{\mathrm{r}} s^{\prime} n^{+}\right)\end{array}$ & $\begin{array}{l}\text { GP6 } \\
\quad\left(t s^{+} \text {PAA }^{s} s y n^{-}\right)\end{array}$ & $t s^{+} \mathrm{PAA}^{\mathrm{r}}$ & $\begin{array}{l}\text { A1E1 } \\
\text { A1E2 } \\
\text { A2D } \\
\text { A4D } \\
\text { A5C } \\
\text { A6D } \\
\text { A1G3 } \\
\text { A7D } \\
\text { A8E }\end{array}$ & $\begin{array}{l}\text { syn }^{+} \\
\text {syn } \\
\text { syn }^{+} \\
\text {syn } \\
\text { syn }^{+} \\
\text {syn } \\
\text { syn }^{+} \\
\text {syn } \\
\text { syn }\end{array}$ & $\begin{array}{c}1.0 \\
1.0 \\
1.0 \\
1.0 \\
0.01 \\
0.8 \\
0.9 \\
<0.01 \\
1.0\end{array}$ \\
\hline B & $\begin{array}{l}17 t s \mathrm{~J} \\
\quad\left(t s^{-} \text {PAA }^{\mathbf{r}} \text { syn }^{+}\right)\end{array}$ & $\left.\stackrel{186}{\left(t s^{+} \mathrm{PAA}^{\mathrm{s}} \text { syn }\right.}{ }^{+}\right)$ & $t s^{+} \mathrm{PAA}^{\mathrm{r}}$ & B1E & $\operatorname{syn}^{+}$ & 1.2 \\
\hline $\mathrm{C}$ & $\begin{array}{l}\text { HFEM } t s \mathrm{~N} 102 \\
\quad\left(t s^{-} \mathrm{PAA}^{\mathbf{r}} \text { syn }^{-}\right)\end{array}$ & $\left.\stackrel{186}{\left(t s^{+} \mathrm{PAA}^{\mathrm{s}} \text { syn }\right.}{ }^{+}\right)$ & $t s^{+} \mathrm{PAA}^{\mathrm{r}}$ & $\begin{array}{l}\text { C1D } \\
\text { C2D } \\
\text { C3D1 } \\
\text { C3D2 } \\
\text { C4D } \\
\text { C5D } \\
\text { C6D } \\
\text { C7D }\end{array}$ & $\begin{array}{l}\text { syn } \\
\text { syn } \\
\text { syn }^{+} \\
\text {syn } \\
\text { syn } \\
\text { syn } \\
\text { syn } \\
\text { syn } \\
\text { syn } \\
\text { syn }\end{array}$ & $\begin{array}{l}1.0 \\
1.0 \\
1.0 \\
0.85 \\
0.1 \\
0.003 \\
0.06 \\
0.75\end{array}$ \\
\hline D & $\begin{array}{l}\mathrm{KOS} t s \mathrm{E} 6 \\
\quad\left(t s^{-} \mathrm{PAA}^{\mathrm{s}} s y n^{+}\right)\end{array}$ & $\begin{array}{l}186 t s \mathrm{~B} 5 \\
\quad\left(t s^{-} \mathrm{PAA}^{\mathrm{s}} \text { syn }^{+}\right)\end{array}$ & $t s^{+} \mathrm{PAA}^{\mathrm{s}}$ & $\begin{array}{l}\text { D1E1 } \\
\text { D1E4 } \\
\text { D1E5 } \\
\text { D3E1 } \\
\text { D3E2 } \\
\text { D4E1 } \\
\text { D4E2 } \\
\text { D4E3 } \\
\text { D5E1 } \\
\text { D5E2 }\end{array}$ & $\begin{array}{c}\text { syn }^{+} \\
\text {partial } s y n^{-} \\
\text {partial } s y n^{-} \\
\text {syn } \\
\text { syn }^{+} \\
\text {syn } \\
\text { syn } \\
\text { syn }^{+} \\
\text {syn } \\
\text { partial } s y n^{+}\end{array}$ & $\begin{array}{l}0.01 \\
1.0 \\
1.0 \\
* b \\
* \\
* \\
* \\
4.0 \\
1.0 \\
1.0\end{array}$ \\
\hline
\end{tabular}

${ }^{a} t s^{-}, t s^{+}$, Temperature-sensitive and wild-type phenotypes, respectively. PAA ${ }^{\mathrm{r}}, \mathrm{PAA}^{\mathrm{s}}$ Genotypes conferring resistance and sensitivity to PAA. syn-, Strain capable of inducing syncytial plaque morphology due to the fusion of indicator cells to form polykaryocytes; $s y n^{+}$, virus has wild-type plaque morphology, i.e., plaques characterized by clumps of rounded cells.

${ }^{b}$ Plaques small at $38.5 \mathrm{C}$ and not readily seen at $33.5 \mathrm{C}$.

both parental and recombinant fragments were present in the same gel. The experimental procedure that minimized the selection of segregating mixtures was to subject the cloned progeny to sonic treatment before replating. The number of plaque purifications of the recombinants ranged from a minimum of three (one recombinant) to a maximum of six. In series $D$, virus stocks were prepared under nonselective conditions after the second or third plaque purification. Consequently, the progeny selected on subsequent recloning might have arisen from additional rounds of recombination.

Biological properties of recombinants. The recombinants selected from this study are listed in Table 1. Each recombinant was designated according to parental cross (series A, B, C, or $D)$, initial clone number (1, 2, etc.), and number of plaque purifications ( $\mathrm{A}, \mathrm{B}$, etc.). In some instances segregation of a mixture of recombinants did not occur until after several plaque purifications, and these were designated by an additional arabic number. Thus, recombinants $\mathrm{A} 1 \mathrm{E} 1$ and A1E2 were derived from series A (Table 1). The progeny of one plaque (no. 1) produced under selective conditions by the product of that cross was plaque-purified five times and carries the designation $\mathrm{E}$. In the last plaque purification, the progeny of two plaques was shown to contain different recombinants, and these were designated 1 and 2 .

Two biological properties of the recombinants are of interest. First, we have noted that all but one of the products of series A cross were $s n^{+}$ even though HSV-2(GP6) is syn ${ }^{-}$(5). In the case of series $\mathrm{C}$, most of the recombinants expressed 
the syn $^{-}$phenotype. In the case of cross $\mathrm{D}$, most of the progeny expressed the syn + phenotype of the parents, and only three recombinants expressed a partially syn $n^{-}$phenotype. In the light of the preponderance of evidence indicating that the plaque morphology phenotype is defined by the virus-specific glycoproteins (reviewed in reference 25) and that the syn phenotype is determined by at least two genes of which one acts as a promoter and the other acts as an inhibitor of fusion (R. Manservigi, P. G. Spear, and A. Buchan, Proc. Natl. Acad. Sci. U.S.A., in press), analysis of the genotype of the recombinants will have to await studies on viral glycoproteins.

The second biological property of interest in the efficiency of plating at 38.5 and $33.5^{\circ} \mathrm{C}$. Most recombinants in all four series had ratios of plating efficiencies characteristic of the wild type. The ratios of plating efficiencies of two series $\mathrm{A}$ and three series $\mathrm{C}$ recombinants were significantly lower than that of the wild type but higher than that of the $t s$ parent, suggesting either partial thermal sensitivity of a hybrid gene product or the existence of additional, partially $t s$ lesions in the DNA of that mutant. Of considerable interest is the observation that two recombinants (D4E1 and D4E2) formed plaques poorly at both temperatures, whereas recombinant D4E3 produced fourfold more plaques at 38.5 than at $33.5^{\circ} \mathrm{C}$. In light of the fact that these recombinants grew at $33.5^{\circ} \mathrm{C}$, the absence or decreased efficiency of plaque formation might reflect a nonlethal defect in a viral gene product. Inasmuch as plaque formation by HSV is a consequence of alteration in the social behavior of cells, the altered gene product may be a virus-induced membrane polypeptide.

Restriction endonuclease mapping of sites of recombinational events: experimental design and data presentation. The parental strains and recombinants were grown in Vero cell cultures $\left(2 \times 10^{6}\right.$ cells $)$ infected at a multiplicity of $5 \mathrm{PFU} /$ cell and incubated in medium containing ${ }^{32} \mathrm{P}$ as described in Materials and Methods. Viral DNA was extracted $24 \mathrm{~h}$ postinfection as described in Materials and Methods, and aliquots were digested with $\mathrm{XbaI}, \mathrm{HsuI}$, $B g l \mathrm{II}, H p a \mathrm{I}$, and $E c o$ RI restriction endonucleases. In some instances the DNA was cut by both $H p a \mathrm{I}$ and $K p n \mathrm{I}$ enzymes. After digestion, the DNA fragments were separated by electrophoresis and autoradiographed as described in Materials and Methods.

Analyses of these results are presented in Fig. 2 through 8 . Figures 2 and 3 present the autoradiographic images and maps for the DNA of a recombinant resulting from a single recombinational event. Figures 4 and 5 present similar data for the DNA of a recombinant resulting from two crossover events, whereas Fig. 6 and 7 present the data for the DNA of a recombinant formed by multiple crossover events. Figure 8 presents the results of analyses of all 28 recombinants examined in this study. Pertinent to the presentations of data are the following. (i) We have chosen to present autoradiographic images rather than drawings of the autoradiographic data even though the resolution of the photographs is not as good as that of the X-ray film. (ii) In presenting the interpretation of the autoradiographic analyses, it was desirable for the sake of simplicity to present only one arrangement of HSV DNA, specifically the one that displayed the minimum number of crossover events. As discussed later in the text, a single arrangement satisfied all recombinants selected for this study. For HSV-1 DNA, this arrangement differs from the prototype arrangement published previously $(9,13,14,18)$ and corresponds to the arrangement previously identified as $\mathrm{I}_{\mathrm{SL}}$. (iii) To enable the reader to follow the reasoning that led to the mapping of these recombinants, it was desirable to juxtapose the colinear arrangements of HSV-1 and HSV-2 DNAs. The colinear arrangements shown in Fig. 3, 5, and 7 became apparent and were verified only after a number of recombinants had been analyzed. (iv) A minor problem bearing on the alignment of HSV-1 and HSV-2 DNAs stems from the observation that although HSV-1 and HSV-2 DNAs cosediment on velocity sedimentation in sucrose density gradients (20), the sum of the molecular weights of HSV-2 restriction endonuclease fragments exceeds that of HSV- 1 by $3 \times 10^{6}$ (Hayward et al., manuscript in preparation). Moreover, it appears that the HSV-2 S component is larger than the HSV-1 S component by a molecular weight of about $1 \times 10^{6}$. To simplify the presentation of the data, we normalized the fragment sizes of HSV-1 and HSV-2 DNAs to yield the sum molecular weight of $100 \times 10^{6}$ and aligned them at the junction of the $L$ and $S$ components. Because of the difference in the relative amounts of DNA in L and S components, the juxtaposed maps shown in Fig. 3, 5, and 7 appear to be staggered. It should be noted that the error introduced by normalization of the sizes of the DNAs did not materially affect the analyses of the recombinants. Thus, although in a few instances we were unable to determine whether a particular cleavage site was derived from HSV-1 or HSV-2 DNA, analysis of the same DNA with another enzyme produced unambiguous results. (v) The boundaries of the probable crossover sites were set 


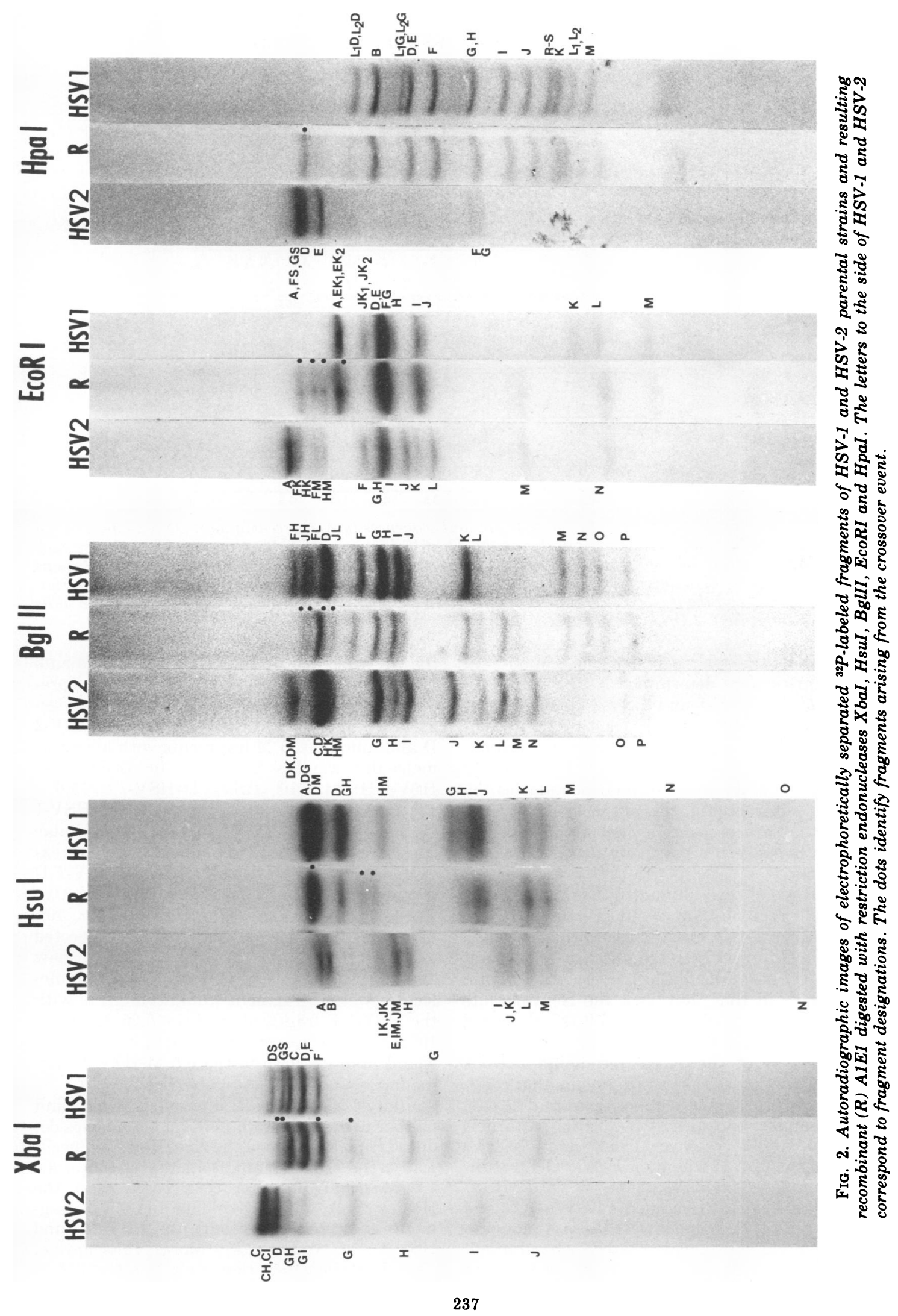




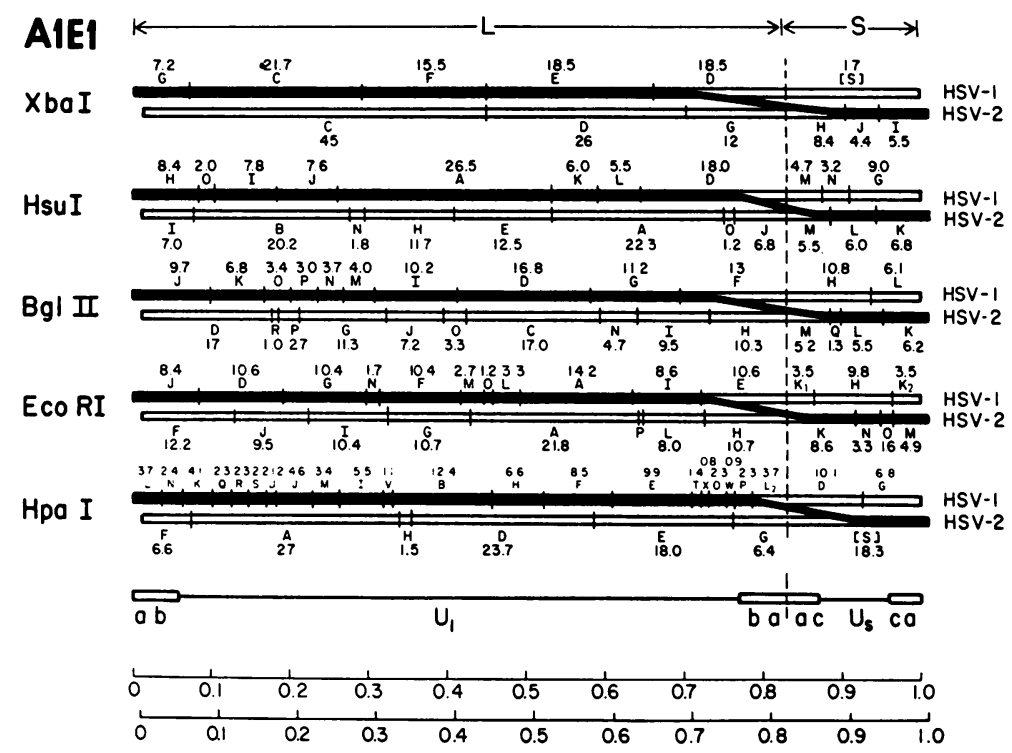

FIG. 3. Identification of HSV-1 and HSV-2 parental sequences in A1E1 recombinant DNA as determined by each restriction endonuclease used in this study. The filled lines indicate the sequences identified by each restriction enzyme as belonging to HSV-1 or HSV-2 parental DNA. The diagonal line linking the two maps spans the boundaries of the crossover events. The steeper the diagonal line, the narrower are the boundaries. The maps represent the prototype arrangement selected in this study. The two lower lines indicate map units for HSV-1 and HSV-2 DNAs, respectively.

independently for each enzyme. Maximum boundaries were determined by the map positions of the HSV-1 and HSV-2 cleavage sites positively identified and bracketing the recombinational site. In some instances the boundaries defining the recombinational event could be further narrowed (minimal boundaries) by taking into account the absence of cleavage sites that are present in one of the parental DNAs between the positively identified cleavage sites.

Analysis of recombinant A1E1, produced by a single recombinant event. Pertinent to the analysis of A1E1 is the observation that the parent strain HSV-1(17) and its ts mutant HSV-1(17 tsJ) differ from our prototype strain HSV-1(F) in that they lack the cleavage site between HpaI fragments S and R (40; Hayward et al., manuscript in preparation).

Digestion of the A1E1 recombinant DNA with $X b a$ I yielded several fragments that comigrated with fragments of both parental DNAs. The simplest interpretation of this pattern is that a single crossover event had occurred within the $0.25 \mathrm{M}$ fragment $\mathrm{HSV}-2 \mathrm{GH}$, resulting in a new 0.25 M fragment, HSV-1 D-HSV2 H. Specifically: (i) fragments HSV-1 G, C, and $F$ and HSV-2 H, I, and $J$ were present in appropriate molar ratios, as indicated by band intensities, and HSV-1 bands D and E comigrated with a broader band in the recombinant; (ii) if the crossover occurred within the fragments HSV-1 D[S] and HSV-2 GH it would be predicted that the recombinant DNA would generate a $0.5 \mathrm{M}$ fragment comigrating with HSV-2 $\mathrm{D}$ and unique $0.25 \mathrm{M}$ fragments with apparent molecular weights of $26.9 \times 10^{6}$ (HSV-1 DHSV-2 H), $24 \times 10^{6}$ (HSV-1 D-HSV-2 I), $15.6 \times$ $10^{6}$ (HSV-1 G-HSV-2 H), and $12.7 \times 10^{6}$ (HSV-1 G-HSV-2 I). The 0.25 M $26.9 \times 10^{6}$-molecular weight recombinant fragment would be expected to comigrate with the 1.0 M HSV-2 D fragment and differ from it only in the relative intensity of the band. The $0.25 \mathrm{M} 24 \times 10^{6}$. molecular weight fragment would be expected to comigrate with $0.25 \mathrm{M}$ HSV-1 G[S] and show similar intensity. The $0.25 \mathrm{M} 15.6 \times 10^{6}$-molecular weight fragment would comigrate with the HSV-1 F fragment, and the 0.25 M $12.7 \times$ $10^{6}$-molecular weight recombinant fragment would migrate close to the $0.5 \mathrm{M} \mathrm{HSV}-2$ fragment.

Analysis of the EcoRI digests confirmed and further defined the recombinant boundaries deduced from analyses of the $X b a I$ digests. Specifically, the recombinant DNA digest contained 1.0 M fragments that comigrated with the HSV-1 M, A, and I fragments and 0.5 M fragments that comigrated with the HSV-1 J and HSV-2 $M$ fragments. More informative, though, is the generation of a new set of $0.25 \mathrm{M}$ fragments, three $\left(19.2 \times 10^{6}, 17.0 \times 10^{6}\right.$, and 


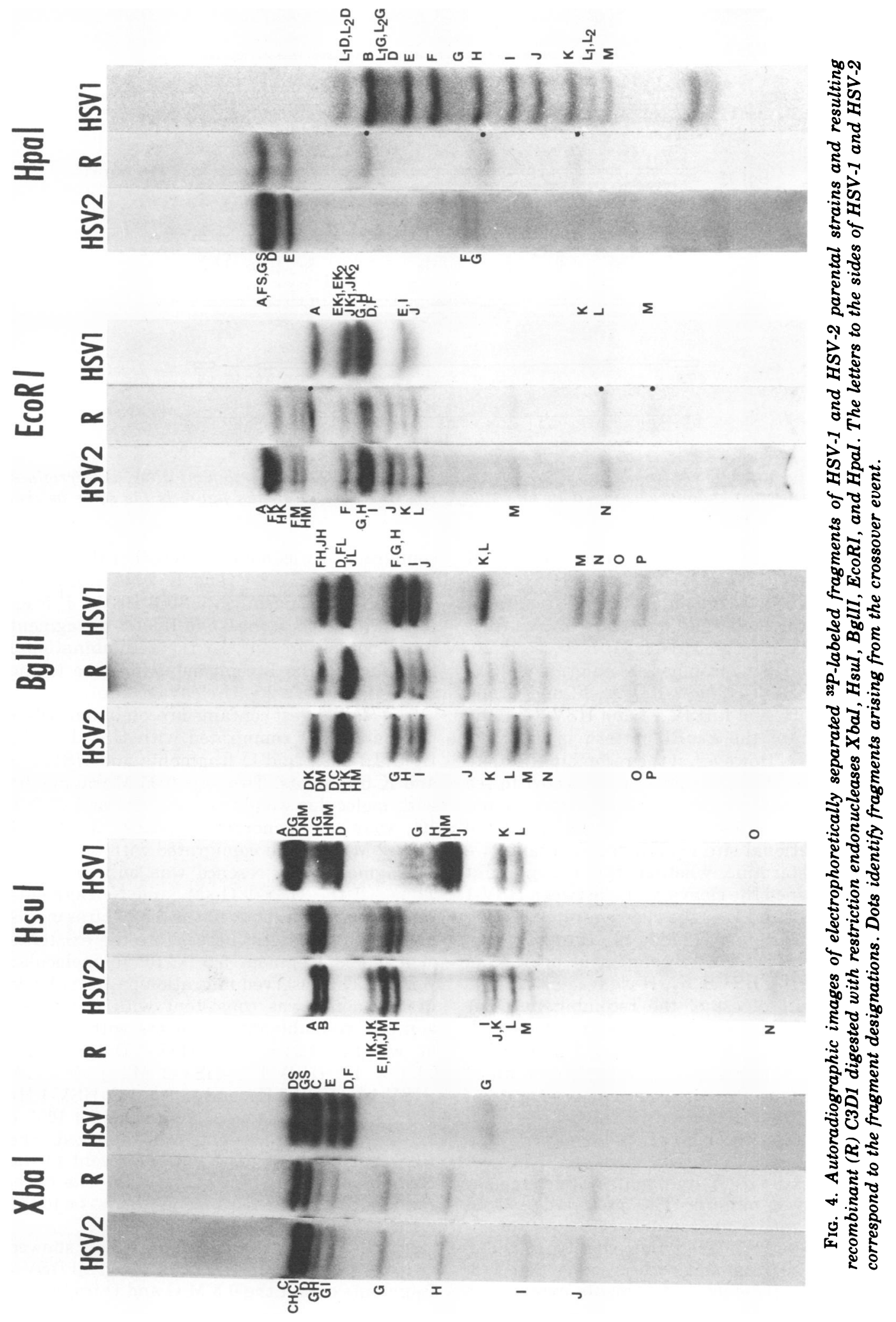




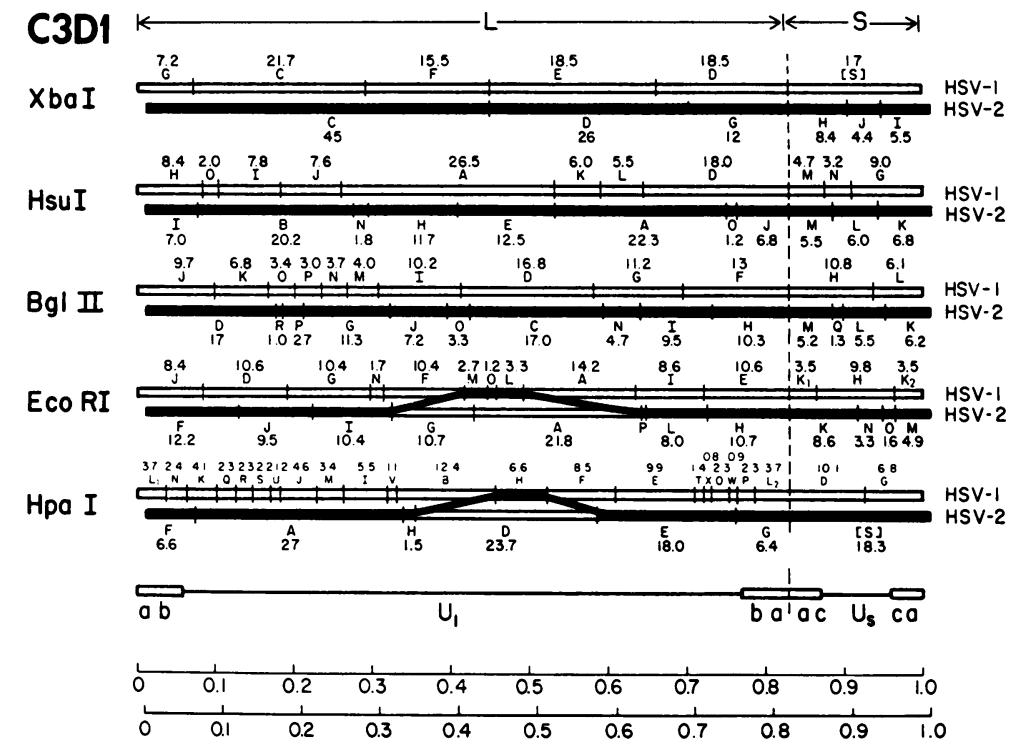

Fig. 5. Identification of HSV-1 and HSV-2 parental sequences in C3D1 recombinant DNA, as determined by each restriction endonuclease used in this study. The construction of this figure is the same as that described in the legend to Fig. 3.

$\left.15.5 \times 10^{6}\right)$ that comigrated with the $0.25 \mathrm{M}$ fragments HSV-2 HK, FM, and HM and a unique $0.25 \mathrm{M}$ fragment, $13.3 \times 10^{6}$ in molecular weight, which could have arisen from fragments HSV-1 J and HSV-2 M. Because many HSV-1 and HSV-2 fragments comigrated (HSV$1 \mathrm{~L}$ and HSV-2 N; HSV-1 D, E, F, and G and HSV-2 G, H, and I; HSV-1 I and HSV-2 K), the remainder of the EcoRI pattern is not very informative. However, if the recombination site were different, we would have expected to see the emergence of new fragments that were not found in the digest. The left boundary of the recombinational site is ambiguous because we cannot determine whether the recombinant DNA retained the cleavage site between HSV-1 fragments I and $\mathrm{E}$ or the cleavage site between HSV-2 fragments $\mathrm{L}$ and $\mathrm{H}$. However, the boundary in the HSV-2 component must be to the left of the HSV-1 $\mathrm{K}_{1}, \mathrm{H}$ cleavage site.

The BglII digest of the recombinant DNA contained fragments that comigrated with HSV-1 F, G, I, J, K, M, N, O, and P and HSV-2 $\mathrm{L}$ and $\mathrm{M}$ fragments. The digests also contained $0.25 \mathrm{M}$ fragments with molecular weights of $19.2 \times 10^{6}, 18.2 \times 10^{6}$, and $15 \times 10^{6}$. Fragments produced from recombinational events in 0.25 M HSV-1 F-HSV-2 K, HSV-1 F-HSV-2 M, and HSV-1 J-HSV-2 M fragments would explain the observed pattern. The predicted $0.25 \mathrm{M}$ fragment with a molecular weight of approximately $16 \times 10^{6}$ migrated too closely to the 1.0 M HSV-1 D fragment to be readily detected. Due to the presence of fragments expected to comigrate, it was not clear whether the HSV-1 $\mathrm{D}$ and $\mathrm{L}$ or HSV-2 $\mathrm{C}$ and $\mathrm{K}$ DNA fragments were present. Inasmuch as the HSV-1 F fragment was present, the $0.5 \mathrm{M}$ HSV- $2 \mathrm{H}$ fragment could not be present, so the recombinational boundary in the $\mathrm{L}$ component must be to the right of the HSV-2 I, H cleavage site.

The $\mathrm{HsuI}$ digest contained recombinant DNA fragments that comigrated with HSV-1 A, D, $\mathrm{H}, \mathrm{I}, \mathrm{J}, \mathrm{K}, \mathrm{L}$, and $\mathrm{O}$ fragments and HSV-2 J and $\mathrm{K}$ fragments. Two new $0.25 \mathrm{M}$ fragments, with molecular weights of $14 \times 10^{6}$ and $15.2 \times$ $10^{6}$, were also generated. Because the $0.5 \mathrm{M}$ HSV-2 M fragment comigrated with the HSV-1 $\mathrm{L}$ fragment, its presence was only inferred. Thus, (i) the HSV-1 G, M, and N fragments were not present, and (ii) the $0.25 \mathrm{M}$ fragments present in the digest necessitate the existence of a $0.5 \mathrm{M}$ fragment $5.5 \times 10^{6}$ in molecular weight. The observed migration pattern of 0.25 $M$ fragments was consistent with the emergence of recombinant fragments with molecular weights of $24.8 \times 10^{6}$ (HSV-1 D-HSV-2 K), $23.5 \times 10^{6}(\mathrm{HSV}-1 \mathrm{D}-\mathrm{HSV}-2 \mathrm{M}), 15.2 \times 10^{6}$ (HSV-1 H-HSV-2 K), and $13.9 \times 10^{6}$ (HSV-1 HHSV-2 M). Because no $0.25 \mathrm{M}$ fragment $12.3 \times$ $10^{6}$ in molecular weight was observed, the HSV-2 $J$ fragment must not be present in the recombinant DNA. Accordingly, the site of recombination in the $\mathrm{L}$ component must be to the right of the HSV-2 O, J cleavage site.

Finally, analysis of the $\mathrm{HpaI}$ digests showed that the recombinant DNA contained all HSV-1 fragments except the $0.5 \mathrm{M} \mathrm{G}$ and $\mathrm{D}$ fragments 


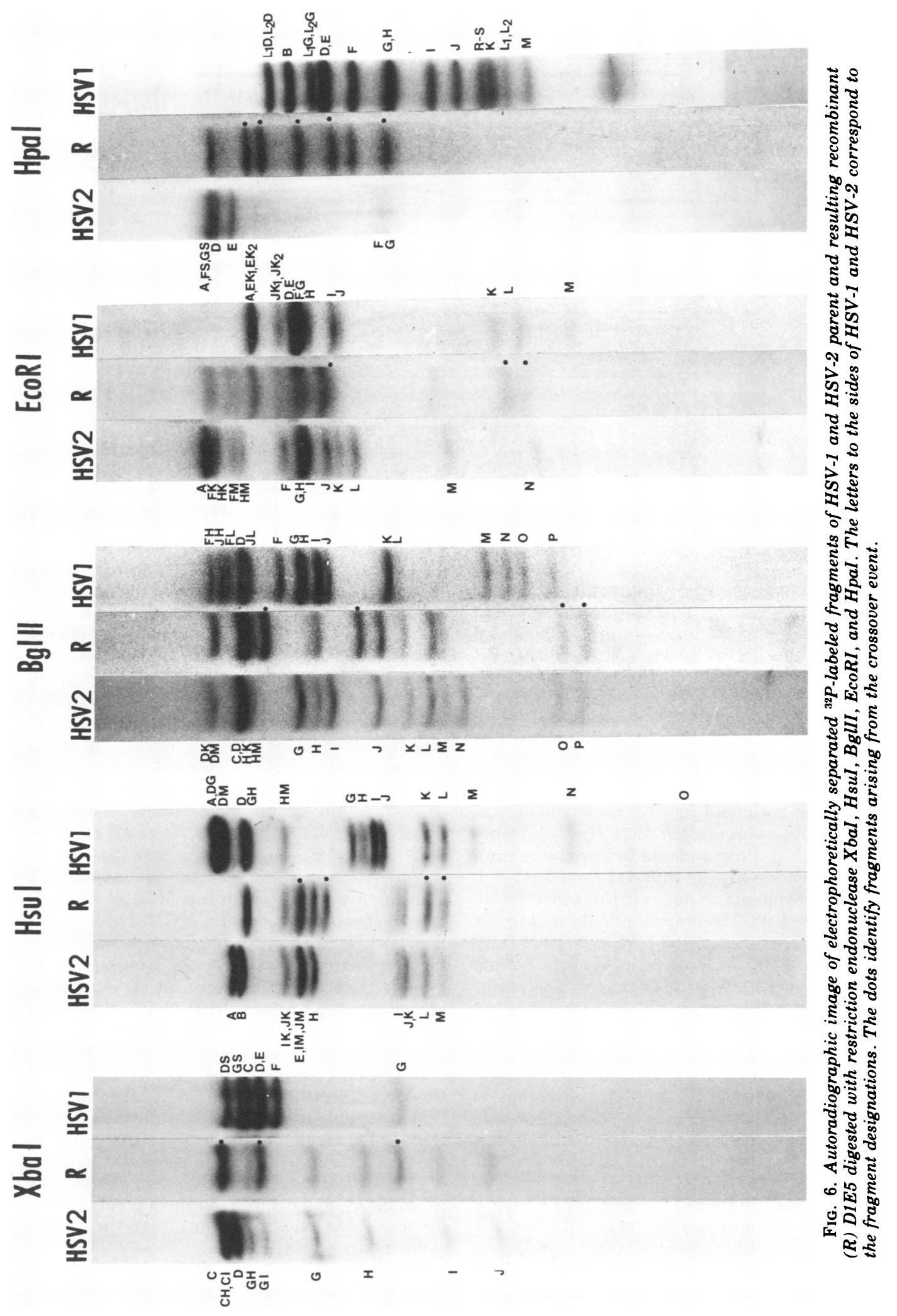




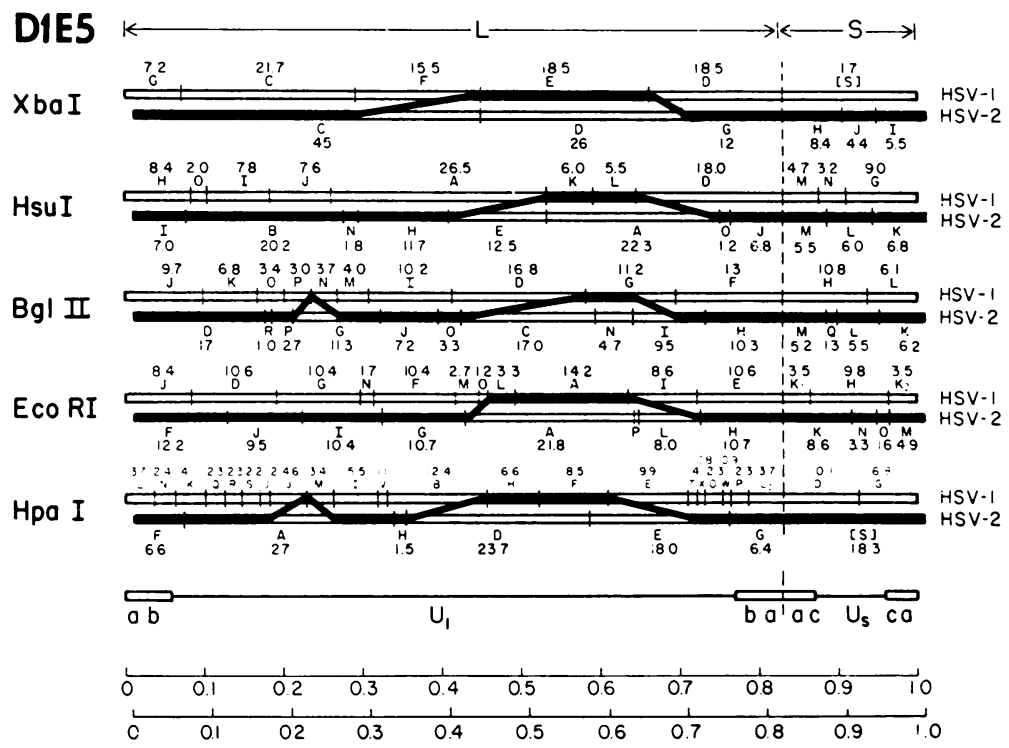

FIG. 7. Identification of HSV-1 and HSV-2 parental sequences in D1E5 recombinant DNA, as determined by each restriction endonuclease used in this study. The construction of this figure is the same as that described in the legend to Fig. 3.

and the resulting $0.25 \mathrm{M}$ fragments associated with them. A new band of appropriate molecular weight $\left(22 \times 10^{6}\right.$ to $\left.23 \times 10^{6}\right)$ arising from the joining of HSV-1 $\mathrm{L}_{1}-\mathrm{HSV}-2$ [S] and HSV-1 $\mathrm{L}_{2}$-HSV-2 [S] fragments was also present. This clearly placed the recombinational boundary to the right of the HSV-1 $\mathrm{L}_{2}$ cleavage site.

The right boundaries of the crossover event were further defined by digesting the recombinant DNA with $K p n \mathrm{I}$ and $\mathrm{HpaI}$ simultaneously. The rationale for this experiment was based on the observation that $\mathrm{HpaI}$ does not cleave HSV-2 $\mathrm{S}$ components but produces multiple cleavages within HSV-2 L and HSV-1 L and $\mathrm{S}$ components. $K p n \mathrm{I}$, on the other hand, cleaves the HSV-2 S component only within the reiterated sequences, producing two $0.5 \mathrm{M}$ fragments $1.2 \times 10^{6}$ in molecular weight and one $1.0 \mathrm{M}$ fragment $16.2 \times 10^{6}$ in molecular weight. Although the KpnI map of HSV-1 DNA has not been constructed, none of the fragments was greater than $8 \times 10^{6}$ in molecular weight. Consequently, if the $\mathrm{S}$ component of the recombinant arises from HSV-2 DNA, digestion of DNA with both enzymes should produce only one high-molecular-weight DNA band $(16.2 \times$ $\left.10^{6}\right)$ and, irrespective of the structure of the remainder of the DNA, numerous bands containing small fragments arising from cleavage of the $\mathrm{L}$ component and the terminal $1.2 \times 10^{6}$ molecular weight fragment of the $S$ component. This is precisely what was found. These data indicate that the crossover event occurred within the $b^{\prime} a^{\prime} a^{\prime} c^{\prime}$ region and that its boundaries are 1.2 map units to the right of the junction of $\mathrm{L}$ and $\mathrm{S}$ and 3.7 map units (HSV-1 $\mathrm{HpaI} \mathrm{P}, \mathrm{L}_{2}$ site) to the left of the junction.

Analysis of recombinant C3D1 DNA formed by a double crossover event. Pertinent to analysis of intertypic recombinants from series $C$ was the observation that the restriction endonuclease maps of HSV-1(HFEM) differ in the following ways from those presented in Fig. 5: (i) a deletion of an approximate molecular weight of $2 \times 10^{6}$ occurs in XbaI D, HsuI D, $B g l$ II F, and EcoRI E fragments; (ii) several fragments from the $\mathrm{S}$ component increase in molecular weight ( $H s u I \mathrm{G}$ and $\mathrm{MN}, B g l \mathrm{II} \mathrm{H}$ and L, HpaI D and G, and EcoRI H); and (iii) the $H s u \mathrm{I} N, \mathrm{M}$ cleavage site is missing, resulting in a fragment of a molecular weight slightly greater than $8 \times 10^{6}$ (Hayward et al., manuscript in preparation). HSV-2(186) gave the same restriction endonuclease cleavage pattern as HSV-2(GP6).

Digestion of recombinant DNA with $X b a \mathrm{I}$, $H s u \mathrm{I}$, and $B g l \mathrm{II}$ restriction endonucleases generated fragments that all comigrated with HSV-2 fragments (Fig. 4 and 5). Inasmuch as the $0.25 \mathrm{M}$ fragments all comigrated with those of the HSV-2 parental DNA fragments, any recombinational event must have involved double crossover events within either the $\mathrm{L}$ or $\mathrm{S}$ components or both.

Digestion of recombinant DNA with EcoRI generated fragments that comigrated with the 


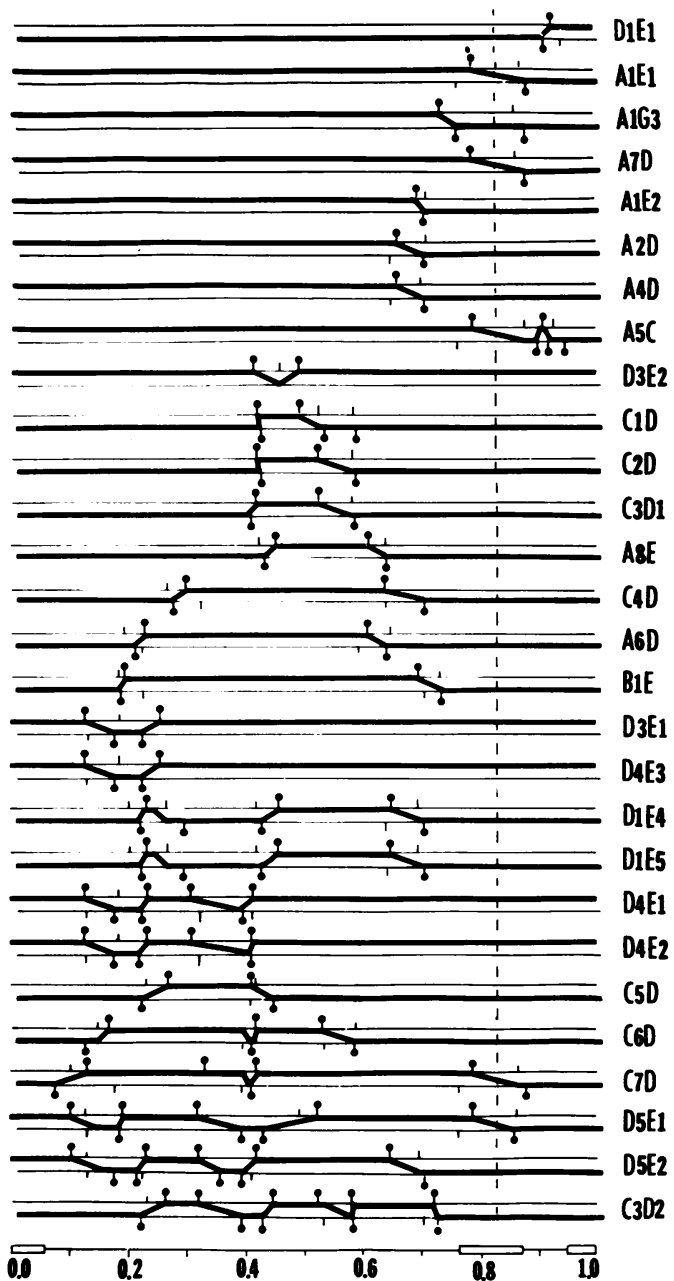

Fig. 8. Summary of the DNA sequence arrangements of all recombinants analyzed in this study. The upper and lower line of each doublet represent HSV-1 and HSV-2 DNAs, respectively. The heavy line indicates the source of parental DNA transposed into the recombinant DNA. The diagonal line spans the boundaries defined by the five restriction endonucleases. Hatch marks at or near the diagonal line identify the critical endonuclease cleavage sites that define the boundaries of the crossover event. The hatch marks with a knob identify the restriction endonuclease cleavage sites retained in recombinant DNA, whereas those without knobs represent sequences absent in the recombinant DNA. The boxes on the map unit line indicate the reiterated sequences of $L$ and $S$ components of HSV DNA.

HSV-1 $M$ and A fragments and the HSV-2 F, H, $\mathrm{I}, \mathrm{J}, \mathrm{K}, \mathrm{L}, \mathrm{M}, \mathrm{N}, \mathrm{O}$, and all $0.25 \mathrm{M}$ fragments. Pertinent to the mapping of the recombinational event is the absence of the HSV-2 A fragment. Accordingly, the simplest interpretation is that a double crossover occurred between the HSV-2 A, P and HSV-1 L, A sites and between the HSV-1 F, M and HSV-2 I, G sites, as shown in Fig. 5.

Digestion of recombinant DNA with $\mathrm{HpaI}$ generated fragments that comigrated with the HSV-2 A, F[S], G[S], E, F, and G and HSV-1 H and $\mathrm{K}$ fragments. A fragment that migrated slightly faster than the HSV-1 B fragment was also observed. Inasmuch as the recombinant fragment that comigrated with the HSV-1 $\mathrm{H}$ and HSV-2 $\mathrm{F}$ and $\mathrm{G}$ fragments was $1.0 \mathrm{M}$ in relative concentration and because the HSV-2 fragment was missing, the most likely interpretation is that a double crossover event occurred between the HSV-2 D, E and HSV-1 H, F sites and between the HSV-1 B, H and HSV-2 H, D sites. The consequences of such a recombinational event would be to generate fragments of molecular weights of $4.1 \times 10^{6}, 6.6 \times 10^{6}$, and $11.5 \times 10^{6}$. The $4.1 \times 10^{6}$-molecular weight fragment would comigrate with the HSV-1 K fragment.

In summary, the results obtained with all five enzymes indicate that the boundaries of the double crossovers are defined by the HSV-2 $H s u \mathrm{I} \mathrm{H}, \mathrm{E}$ and HSV-1 Eco RI F, M sites and by the HSV-1 HpaI H, F and HSV-2 HpaI D, E cleavage sites, as shown in Fig. 5 .

Analysis of recombinant D1E5 DNA formed by multiple crossover events. Digestion of the Houston strain of KOS DNA with the restriction endonucleases used in this study yielded the same DNA fragments as those previously described for strain HSV-1 (17).

Digestion of D1E5 DNA with $X b a$ I generated fragments that comigrated with the HSV-2 G, $\mathrm{H}, \mathrm{I}, \mathrm{J}$, and all $0.25 \mathrm{M}$ fragments and the HSV-1 $\mathrm{E}$ fragment (Fig. 6). A unique fragment with an approximate molecular weight of $6.5 \times 10^{6}$ was also observed. Because fragments that comigrated with the HSV-2 $0.25 \mathrm{M}$ fragments were present, this recombinant must have arisen from multiple crossover events within either the $\mathrm{L}$ or $\mathrm{S}$ components (Fig. 7). Inasmuch as the HSV-2 D and HSV-1 C or G fragments were not present, a crossover between the HSV-2 D, G and HSV-1 E, D sites and between the HSV-1 $\mathrm{F}, \mathrm{E}$ and $\mathrm{C}, \mathrm{F}$ sites would explain the observed migration pattern. This would generate fragments that would comigrate with the HSV-2 O and $\mathrm{P}$ fragments.

The HsuI digest contained fragments that comigrated with the HSV-2 B, H, I, J, K, L, M, $\mathrm{N}$, and all $0.25 \mathrm{M}$ fragments. Of significance were the observations of the new fragment, which migrated with an apparent molecular weight of $10 \times 10^{6}$, the absence of the HSV-2 A fragment, and the $1.0 \mathrm{M}$ recombinant fragment that comigrated with the HSV-1 L and HSV-2 $M$ fragments. Inasmuch as the digest contained 
$0.25 \mathrm{M}$ fragments indistinguishable from HSV$20.25 \mathrm{M}$ fragments, the recombinant must contain the HSV-2 $\mathrm{M}$ fragment. Accordingly, a recombinational event occurring between the HSV-2 A, O and HSV-1 L, D sites and between the HSV-1 A, K and HSV-2 H, E sites would explain the observed fragment pattern.

The EcoRI digest contained fragments that comigrated with HSV-2 F, J, I, M, N, O, K, and all $0.25 \mathrm{M}$ fragments and HSV-1 A, I, and M fragments. Of significance were the observations that the HSV-1 M fragment was absent and the appearance of a new fragment with an apparent molecular weight of $3.7 \times 10^{6}$. It is not clear whether the HSV-2 L, H or HSV-1 I, E site was present. However, because a fragment that comigrated with the HSV-1 I fragment was present, the crossover event most likely occurred between the HSV-2 L, H and HSV-1 A, I sites and between the HSV-1 O, L and HSV-2 G, L sites.

The $B g l I I$ digest contained fragments which comigrated with HSV-2 D, P, J, H, M, L, K, O, and all $0.25 \mathrm{M}$ fragments. Inasmuch as HSV-2 $\mathrm{C}$ and HSV-1 D comigrated, it is not clear which is present in the recombinant DNA. Unique fragments with approximate molecular weights of $8 \times 10^{6}$ and $14 \times 10^{6}$ were observed. Because neither the HSV-1 J nor the HSV-1 F fragment was present, a crossover between the HSV-2 I, H and N, I sites must have occurred, which would generate a fragment with an approximate molecular weight of $14 \times 10^{6}$. Inasmuch as the HSV-2 $\mathrm{J}$ and $\mathrm{O}$ fragments were present, another crossover between the HSV-1 $\mathrm{D}, \mathrm{J}$ and HSV-2 $\mathrm{O}, \mathrm{C}$ sites must also have occurred. Finally, because the HSV-2 G fragment was absent and because a unique fragment migrating with an apparent molecular weight of $8 \times 10^{6}$ was generated, a small double crossover between the HSV-2 G, J and HSV-1 $\mathrm{P}, \mathrm{N}$ sites and between the HSV-1 P, N and HSV-2 P, G cleavage sites most likely also had occurred.

The HpaI digest contained fragments that comigrated with HSV-2 G, F, A, G[S], F[S], and HSV-1 $\mathrm{H}$ and $\mathrm{F}$ fragments. Unique fragments with approximate molecular weights corresponding to $10 \times 10^{6}, 11.5 \times 10^{6}, 14 \times 10^{6}$, and $17 \times 10^{6}$ were also observed. Because the HSV-2 $\mathrm{E}$ and HSV-1 $\mathrm{E}$ fragments were absent, a crossover event must have occurred to the left of the HSV-1 E, T site but to the right of the HSV-2 D, E site. A fragment with an approximate molecular weight of $14 \times 10^{6}$ would be generated if the HSV-1 F, E cleavage site were present. Inasmuch as the HSV-1 $\mathrm{H}$ fragment was present whereas the $B$ fragment was not, another crossover between the HSV-1 B, H and
HSV-2 H, D sites, generating a unique fragment with an approximate molecular weight of $11.5 \times 10^{6}$, must have occurred. Finally, a small double crossover between a portion of the HSV2 A fragment and the HSV-1 J, M site would generate two unique fragments with apparent moleular weights of $10 \times 10^{6}$ and $17 \times 10^{6}$, consistent with the BglII fragment pattern.

In summary, the results obtained with all five enzymes (Fig. 6) indicate that four recombinational events must have occurred. The minimum boundaries of the crossover site appear to be between (i) the HSV-2 XbaI D, G and HSV-1 XbaI E, D cleavage sites, (ii) the HSV-1 EcoRI F, M and HSV-2 HsuI H, E sites, (iii) the HSV-2 BglII G, J and HSV-1 HpaI J, M sites, and (iv) the HSV-1 HpaI J, M and HSV-2 EcoRI J, I sites. Figure 7 shows the map positions of the minimal boundaries.

Summation of recombinant analyses. Figure 8 shows the results of the restriction endonuclease analyses of the intertypic recombinants isolated in this study. Several points emerge from this figure. (i) Although the experiments were designed to ensure the isolation and analysis of progeny of independent recombinational events, there was segregation of recombinants even after multiple plaque purifications. In some instances, e.g., D4E1 and D4E2, the segregants resembled each other, suggesting that after the original recombinational event some progeny within the clone underwent additional recombinational events. For example, D4E1 and D4E2, which segregated only after five plaque purifications, differ slightly and therefore may be clonally related. The same is probably true for A2D, A4D, D1E4, and D1E5. D5E1 and D5E2 may also be clonally related, even though here the differences are more extensive. However, D1E1 is clearly different from D1E4 and D1E5, even though it segregated only after five plaque purifications from the same original clone. Therefore, D1E1 is, most likely, the product of a different recombinational event. We have chosen to retain clonally related recombinants in our summary because preliminary polypeptide analysis has revealed at least one polypeptide difference between some recombinants with identical DNA maps, as far as we have been able to detect.

(ii) Analyses of the recombinants permit physical mapping of some markers used in this study. For example, PAA $^{r}$ appears to map between map unit positions 0.43 and 0.52 . This is apparent from analyses of recombinant C1D and C2D. The maps of all other recombinants in which PAAr was used as a marker are consistent with this interpretation. These data are also consistent with genetic mapping data from 
two-factor crosses (33; J. Jofre, P. A. Schaffer, and D. Parris, manuscript in preparation). Similarly, we noted that PAA ${ }^{r}$ and the syn phenotype cosegregate. Several considerations, including genetic crosses and marker rescue (D. Knipe, W. Ruyechan, and B. Roizman, manuscript in preparation), argue that at least one of the two genes defining the syn marker maps to the left of PAAr. In addition, $t s \mathrm{~J}$ must map to the right of map unit position 0.78 . There is less certainty as to the position of $t s \mathrm{~B} 5$, $t s \mathrm{E} 6$, and $t s \mathrm{~N} 102$, although the data may be interpreted to indicate that $t s \mathrm{~B} 5$ maps to the right of 0.49 .

(iii) There is an indication that there exist preferential crossover sites. We have observed the occurrence of many recombinational events in regions defined by map units 0.40 to 0.45 and 0.60 to 0.70 . In reviewing the parental phenotypes, it is clear that the recombinants selected for $\mathrm{PAA}^{\mathrm{r}}$ would have to include the HSV-1 DNA bounded by map positions 0.43 to 0.53 . It could also have been predicted that the recombinants selected for the PAA ${ }^{\mathrm{r}}$ marker would exhibit random crossover events beyond that locus in at least some of the parental crosses. It is surprising, therefore, that the crossover events in all parental cross series occur so frequently at or near 0.42 map units to the left of $\mathrm{PAA}^{\mathrm{r}}$. Similar arguments hold for the frequency of recombinational events occurring between map positions 0.60 and 0.70 . Although some of the recombinants with crossovers in these positions are clearly clonally related in the sense that they may have arisen from the progeny of a recombinant that had undergone additional recombinational events, clonal relatedness cannot explain the apparently preferential location of some crossover sites.

\section{DISCUSSION}

Sequence arrangement in HSV-1-HSV-2 recombinants. The major structural features of the recombinants analyzed to date and summarized in Fig. 8 are as follows.

(i) There is wide and extensive interchange of genomic regions and components. These range from complete interchanges of $L$ and $S$ components to substitutions of regions within $L$ and $S$ components. We should also note that within the same component ( $\mathrm{L}$ or S), the reiterated $a b$ or $a c$ sequences can be heterogeneous, as in the case of recombinants A1G3, A2D, D3E1, A4D, D5E1, D5E2, and D1E1.

(ii) Subject to the limits imposed by the number of recombinants analyzed in this study, crossover events seem to occur more frequently in some areas, such as in regions defined by map units 0.62 to 0.69 and around a region defined by map unit 0.40 .

(iii) Most recombinants were formed by more than one crossover event. Double crossovers, which resulted in transposition of stretches of DNA, are of two kinds. The first involves long and readily identifiable regions. The second type involves transposition of relatively small regions, as, for example, in recombinants $\mathrm{A} 5 \mathrm{C}$, C6D, and clonally related D1E4 and D1E5. In these recombinants the crossover events were detected only because the transposed region contained a recognized restriction enzyme cleavage site. Small transposed DNA regions that do not contain a restriction enzyme cleavage site would not be detected. Inasmuch as it is unlikely that small transpositions invariably occur around a known cleavage site, we must conclude that they are much more numerous than we detected in this study. However, pertinent to the conclusions to be discussed below, all microtranspositions, by definition, involve double crossover events.

The functional significance of the structures of the recombinant DNAs stems from the following considerations. First, the interchange of $\mathrm{L}$ and $\mathrm{S}$ components and of smaller regions necessarily argues that the linear orders of the genes of HSV-1 and HSV-2 essential for the replication of the virus are, at least, grossly identical. By this we mean that the genes contained in a transposed region of the DNA must specify the same functions as those in the replaced region. However, without additional analysis of the large transposed regions, we cannot be certain that the order of genes is actually identical in all functionally homologous HSV-1 and HSV-2 regions. Second, because most recombinants analyzed in this study appear to multiply as well as the parental types and do not appear to have obvious defects, we must conclude that, at least for the recombinants selected so far, HSV-1 gene products can complement and interact with HSV-2 gene products and vice versa.

Of special interest, in the context of this conclusion, are the recombinants consisting of HSV-1 L and HSV-2 S components. In the light of the fact that HSV-1 $\alpha$ functions $(15,30)$ map in both $\mathrm{S}$ and $\mathrm{L}$ components (18), it is noteworthy that the intermixing of HSV-1 and HSV-2 templates, both within and between coordinately regulated genes, yielded viable progeny.

Finally, the observation that recombinants contained preferred regions of crossover sites may have several nonexclusive explanations. Thus, the preponderance of the HSV-2 component in the recombinants obtained so far might be a reflection of the parental genotypes used in 
these studies. It might also reflect the possibility that the HSV-2 S component contains sequences that enhance the viability of the recombinants. The clustering of crossover events in certain regions of the DNA might reflect the conservation of type-specific structural or regulatory sites that enhance the viability of the recombinants, non-colinearity of some essential function, or simply a region that shows minimal evolutionary divergence, which would favor legitimate recombination. Discrimination among these various alternatives requires analyses of the recombinants produced by many more crosses. In any event, our data do not contradict the conclusions of Oakes et al. (24) that homologous regions are dispersed throughout HSV-1 and HSV-2 DNAs.

Of the methods currently available for determining the positions and order of markers on the viral genome (i.e., classical recombination analysis, marker rescue, and intertypic recombination), the usefulness of the first $(32,33)$ and second (41; D. Parris and P. A. Schaffer, manuscript in preparation) procedures have been demonstrated in the HSV system. The present study represents the first successful attempt to locate markers on the HSV genome by intertypic recombination, as exemplified by the ability to identify the most probable boundaries of some of the markers used in this study.

Significance of the structure of recombinant DNA and its implications for the function of the various arrangements of HSV-1 and HSV-2 DNAs. The central question that we wish to pose is whether all arrangements of HSV-1 and HSV-2 DNAs could have participated in the generation of the recombinants observed in this study. Our argument, illustrated in Fig. 9, is as follows. Let us assume that parental types each have one marker in either the $\mathrm{L}$ or the $\mathrm{S}$ component and that selection against the markers yields a recombinant generated by a single crossover event in the $L$ component. As Fig. 9 illustrates, if the recombinant event occurs in all arrangements of HSV-1 and HSV-2 DNAs and if all these recombinants are then replicated, the display of the resulting recombinants in the $P$ arrangement should show a single crossover event if the recombination occurred in the $\mathrm{P}$ and $\mathrm{I}_{\mathrm{S}}$ arrangement and $\mathrm{a}$ double crossover event if the recombination occurred in the $I_{L}$ and $I_{S L}$ arrangement. Similarly, if the crossover event occurred in the $S$ component (not shown), rearrangement of the recombinant in the $\mathrm{P}$ arrangement should display a single crossover if the recombination occurred in the $\mathrm{P}$ and $\mathrm{I}_{\mathrm{L}}$ arrangement and a double crossover if the recombination occurred in the $I_{S}$ and $\mathrm{I}_{\mathrm{SL}}$ arrangement. This argument can be ex-

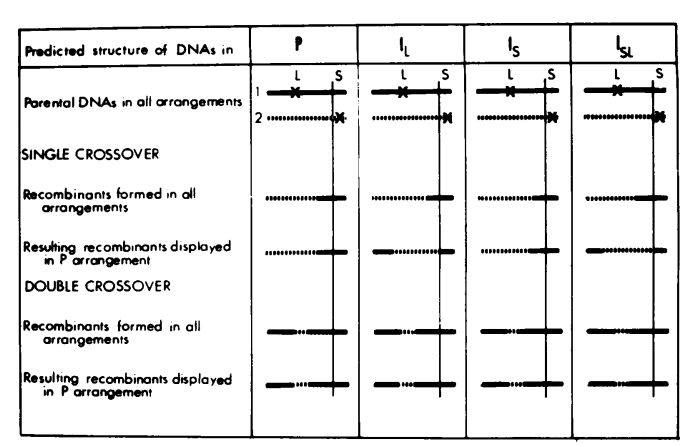

FIG. 9. Predicted recombinant DNA structure generated by selection against markers in the $L$ and $S$ components. The diagram illustrates the predicted recombinant DNA structure for single or double crossover events generated if all arrangements of HSV-1 and HSV-2 DNAs could have participated in the recombinational event. The $X$ present in either the L or $S$ components of parental DNAs indicates the position of the hypothetical markers. The solid lines represent a portion of DNA unique to one parent, whereas the broken lines designate the DNA sequences of the second parent.

tended to any number of crossover events, provided that they are odd in number. In principle, the argument predicts that if recombinational events occur in all four forms of HSV DNA, there should be no single arrangement of recombinant DNAs showing one or an odd number of crossover events. As noted earlier in the text, all could be shown in one arrangement (Fig. 8) that displays the minimal number of crossover events. Analysis of the recombinants obtained so far indicates that they fall into two classes. The majority (18 of 28 ) have an even number of recombinational events, and (as shown diagrammatically in Fig. 9) these neither support nor contradict our argument. Of the 10 that show an odd number of crossover events, 4 nonclonally related recombinants (A1G3, A2D, A1E2, and D5E2) could have arisen from $\mathrm{P}$ or $\mathrm{I}_{\mathrm{S}}$ arrangements of parental DNAs since the crossovers are entirely in L. At least one (D1E1) could have arisen from the $P$ or $I_{L}$ arrangement of the parental DNAs, since the crossover occurs in $\mathrm{S}$. The common arrangement to all is the $P$ arrangement, in which we have chosen to display our data.

The data presented in this paper support the hypothesis that only one or, at best, two arrangements of HSV DNA are replicated. The strengths, weaknesses, and implications of this hypothesis are as follows.

(i) The hypothesis that $I_{\mathrm{L}}$ and $\mathrm{I}_{\mathrm{SL}}$ arrangements do not participate in the generation of recombinants is supported by the observation that all four recombinants with an odd number 
of crossover events in unique sequences of $\mathrm{L}$ are best represented in either the $P$ or the $I_{S}$ arrangement. The hypothesis that $\mathrm{I}_{\mathrm{S}}$ and $\mathrm{I}_{\mathrm{SL}}$ arrangements do not participate in the generation of recombinants is supported by only one (D1E1) recombinant with a single crossover in unique sequences of $\mathrm{S}$ and, therefore, is less tenable.

(ii) Supporting the hypothesis that only one form of HSV DNA replicates is the observation that all mutants analyzed to date can be arranged in a single linear array both for markers within either the $\mathrm{L}$ or $\mathrm{S}$ component and for markers in $\mathrm{L}$ with respect to those in $\mathrm{S}$ $(3,32,33,37)$. As indicated at the time that the four arrangements of DNA were shown to exist (14), this should not be possible if all arrangements are replicated.

(iii) The hypothesis that only one, or at most two, arrangements of HSV DNA are replicated has two significant implications. First, the hypothesis implies that if only $\mathrm{P}$ and $\mathrm{I}_{\mathrm{S}}$ forms replicate, the discriminatory signal must be in the $\mathrm{L}$ terminus of the DNA, and, once DNA synthesis is initiated, it will not discriminate between $P$ and inverted arrangements of the $S$ region. Similarly, if $P$ and $I_{L}$ forms replicate, the discriminatory signal must be in the $\mathrm{S}$ terminus of the DNA. If only the $\mathrm{P}$ arrangement replicates, the discriminatory signal must be at the junction of $\mathrm{L}$ and $\mathrm{S}$ components. Second, the hypothesis implies that rearrangements of HSV DNA occur during an obligatory, postDNA synthesis event for the simple reason that a nonobligatory event could not account for the equimolar concentrations of the four arrangments of DNA. Current studies on the replication of HSV DNA have yielded information that is consistent with the hypothesis that the inversions of $\mathrm{L}$ and $\mathrm{S}$ regions are postreplication events associated with repair synthesis of unit-length DNA excised from concatemers (17; unpublished data). They do not specifically pinpoint the site of initiation of DNA synthesis largely because of the difficulty in differentiating initiation of DNA synthesis and repair of preexisting nicks and gaps. It should be noted, however, that final proof of the hypothesis presented here requires three additional series of experiments. First, additional recombinants with odd numbers of crossover events in $S$ are required to determine whether, in fact, only $P$ or both $\mathrm{P}$ and $\mathrm{I}_{\mathrm{S}}$ participate in the generation of recombinants. Second, additional studies are required on the terminal sequences of the recombinants currently shown to have been formed by an odd number of recombinant events. The problem arises from the fact that none of the restriction enzymes that have been used to construct physical maps of HSV DNA cleave within $1.2 \times 10^{6}$ in molecular weight from the terminus of the S component of HSV-2 DNA, $3.5 \times 10^{6}$ in molecular weight from the terminus of the S component of HSV-1 DNA, $6.4 \times 10^{6}$ in molecular weight from the terminus of the L component of HSV-2 DNA, and $3.7 \times 10^{6}$ in molecular weight from the terminus of the L component of HSV-1 DNA. Therefore, a crossover event occurring within the terminal region $a$ or distal portions of $a b$ and $a c$ regions would not be detected. Lastly, the theoretical prediction regarding the site of initiation of DNA synthesis must be confirmed by experimental studies. These studies are currently in progress.

\section{ACKNOWLEDGMENTS}

The studies conducted at the University of Chicago were aided by grants from the National Cancer Institute, U.S. Public Health Service (CA 08494 and CA 19264), the American Cancer Society (VC 103L), and the National Science Foundation (PCM 76-06254). The studies at Sidney Farber Cancer Institute, Harvard Medical School, were aided by grants from the National Cancer Institute, U.S. Public Health Service (CA 10893 and CA 20260). L. S. M. is a predoctoral trainee (5-T32 GM07183). T. G. B. is a MSTP trainee (5-T32 GM07281).

\section{LITERATURE CITED}

1. Aron, G. M., D. J. M. Purifoy, and P. A. Schaffer. 1975. DNA synthesis and DNA polymerase activity of herpes simplex virus type 1 temperature-sensitive mutants. J. Virol. 16:498-507.

2. Becker, Y., H. Dym, and I. Sarov. 1968. Herpes simplex virus DNA. Virology 36:184-192.

3. Benyesh-Melnick, M., P. A. Schaffer, R. J. Courtney, J. Esparaza, and S. Kimura. 1974. Viral gene functions expressed and detected by temperature-sensitive mutants of herpes simplex virus. Cold Spring Harbor Symp. Quant. Biol. 39:731-746.

4. Bronson, D. L., B. J. Graham, H. Ludwig, M. Benyesh-Melnick, and N. Biswal. 1972. Studies on the relatedness of herpes viruses through DNA-RNA hybridization. Biochim. Biophys. Acta 259:24-34.

5. Cassai, E., R. Manservigi, A. Corallini, and M. Terni. 1975. Plaque dissociation of herpes simplex viruses: biochemical and biological characters of the viral variants. Intervirology 6:212-223.

6. Clements, J. B., R. Cortini, and N. M. Wilkie. 1976. Analysis of herpesvirus DNA substructure by means of restriction endonucleases. J. Gen. Virol. 30:243256.

7. Delius, H., and J. B. Clements. 1976. A partial denaturation map of herpes simplex virus type 1 DNA: evidence for inversions of the unique DNA regions. J. Gen. Virol. 33:125-134.

8. Esparaza, J., M. Benyesh-Melnick, and P. A. Schaffer. 1976. Intertypic complementation and recombination between temperature-sensitive mutants of herpes simplex types 1 and 2. Virology 70:372-384.

9. Frenkel, N., H. Locker, W. Batterson, G. S. Hayward, and B. Roizman. 1976. Anatomy of herpes simplex virus DNA. VI. Defective DNA originates from the S component. J. Virol. 20:527-531.

10. Frenkel, N., and B. Roizman. 1971. Herpes simplex virus: genome size and redundancy studies by renaturation kinetics. J. Virol. 8:591-593. 
11. Grafstrom, R. H., J. C. Alwine, W. L. Steinhart, C. W. Hill, and R. W. Hyman. 1975. The terminal repetition of herpes simplex virus DNA. Virology 67:144157.

12. Grodzicker, T., J. Williams, P. Sharp, and J. Sambrook. 1974. Physical mapping of temperature-sensitive mutations of adenoviruses. Cold Spring Harbor Symp. Quant. Biol. 39:439-446.

13. Hayward, G. S., N. Frenkel, and B. Roizman. 1975. The anatomy of herpes simplex virus DNA: strain difference and heterogeneity in the location of restriction endonculease sites. Proc. Natl. Acad. Sci. U.S.A. 72:1768-1772.

14. Hayward, G. S., R. J. Jacob, S. C. Wadsworth, and B. Roizman. 1975. Anatomy of herpes simplex virus DNA: evidence for four populations of molecules that differ in the relative orientations of their long and short segments. Proc. Natl. Acad. Sci. U.S.A. 72:4234-4247.

15. Honess, R. W., and B. Roizman. 1974. Regulation of herpesvirus macromolecular synthesis. I. Cascade regulation of the synthesis of three groups of viral proteins. J. Virol. 14:8-19.

16. Hyman, R. W., S. Burke, and L. Kudler. 1976. A nearby inverted repeat of the terminal sequence of herpes simplex virus DNA. Biochem. Biophys. Res. Commun. 68:609-615.

17. Jacob, R. J., and B. Roizman. 1977. Anatomy of herpes simplex virus DNA. VIII. Properties of the replicating DNA. J. Virol. 23:394-411.

18. Jones, P. C., G. S. Hayward, and B. Roizman. 1977. Anatomy of herpes simplex virus DNA. VII. $\alpha$ RNA is homologous to noncontiguous sites in both $L$ and $S$ components of viral DNA. J. Virol. 21:268-276.

19. Kieff, E., B. Hoyer, S. Bachenheimer, and B. Roizman. 1972. Genetic relatedness of type 1 and type 2 herpes simplex viruses. J. Virol. 9:738-745.

20. Kieff, E. D., S. L. Bachenheimer, and B. Roizman. 1971. Size, composition, and structure of the deoxyribonucleic acid of herpes simplex virus subtypes 1 and 2. J. Virol. 8:125-132.

21. Mao, J. C.-H., E. E. Robishaw, and L. R. Overby. 1975. Inhibition of DNA polymerase from herpes simplex virus-infected Wi-38 cells by phosphonoacetic acid. J. Virol. 15:1281-1283.

22. Marsden, H. S., I. K. Crombie, and J. H. SubakSharpe. 1976. Control of protein synthesis in herpesvirus-infected cells: analysis of the polypeptides induced by wild type and sixteen temperature-sensitive mutants of HSV strain 17. J. Gen. Virol. 31:347-372.

23. Mautner, V., J. Williams, J. Sambrook, P. A. Sharp, and T. Grodzicker. 1975. The location of the genes coding for hexon and fiber proteins in adenovirus DNA. Cell 5:93-99.

24. Oakes, J., R. Hyman, and F. Rapp. 1976. Genome location of polyadenylated transcripts of herpes simplex virus type 1 and type 2 DNA. Virology 75:145157.

25. Overby, L. R., E. E. Robishaw, J. B. Schleicher, A. Rueter, N. L. Shipkowitz, and J. C-H. Mao. 1974. Inhibition of herpes simplex virus replication by phosphonoacetic acid. Antimicrob. Agents Chemother. 6:360-365.

26. Purifoy, D. J. M., and M. Benyesh-Melnick. 1975. DNA polymerase induction by DNA-negative temperaturesensitive mutants of herpes simplex virus type 2 . Virology 68:374-386.

27. Roizman, B., and D. Furlong. 1974. The replication of herpesviruses, p. 299-403. In H. Fraenkel-Conrat and R. R. Wagner (ed.), Comprehensive virology, vol. 3. Plenum Publishing Corp., New York.

28. Roizman, B., G. Hayward, R. Jacob, S. W. Wadsworth, N. Frenkel, R. W. Honess, and M. Kozak. 1975. Human herpesvirus 1: a model for molecular organization and regulation of herpesviruses, p. 3-38. In G de The, M. A. Epstein, and H. zur Hausen (ed.) Proceedings of the Symposium on Herpesviruses and Oncogenesis, Nurenberg, October 14-16, 1974. I.A.R.C., Lyons.

29. Roizman, B., G. Hayward, R. Jacob, S. W. Wadsworth, and R. W. Honess. 1974. Human herpesvirus 1: a model for molecular organization of herpesvirus virions and their DNA, p. 188-198. In P. Bucalossi (ed.), Proceedings of the 11th International Cancer Congress, vol. 2, Chemical and viral oncogenesis. NorthHolland Publishing Co., New York.

30. Roizman, B., M. Kozak, R. W. Honess, and G. Hayward. 1974. Regulation of herpesvirus macromolecular synthesis: evidence for multilevel regulation of herpes simplex 1 RNA and protein synthesis. Cold Spring Harbor Symp. Quant. Biol. 39:687-702.

31. Roizman, B., and P. R. Roane, Jr. 1961. A physical difference between two strains of herpes simplex virus apparent on sedimentation in cesium chloride. Virology 15:75-79.

32. Schaffer, P. A. 1975. Temperature-sensitive mutants of herpesviruses. Curr. Top. Microbiol. Immunol. 70: 51-100.

33. Schaffer, P. A., and R. J. Courtney. 1976. Genetics of herpesviruses, p. 545-617. In A. Huang, D. Baltimore, and C. Fred Fox (ed.), Animal virology. Plenum Publishing Corp., New York.

34. Sheldrick, P., and N. Berthelot. 1974. Inverted repetitions in the chromosome of herpes simplex virus. Cold Spring Harbor Symp. Quant. Biol. 39:667-678.

35. Skare, J., and W. C. Summers. 1977. Structure and function of herpesvirus genomes. II. Eco RI, Xba I, and Hind III endonuclease cleavage sites on herpes simplex virus type 1 DNA. Virology 76:581-596.

36. Smith, H. O., and D. Nathans. 1973. A suggested nomenclature for bacterial host modification and restriction systems and their enzymes. J. Mol. Biol. 81:419.

37. Subak-Sharpe, J. H., J. M. Brown, D. A. Ritchie, M. C. Timbury, J. C. M. Macnab, H. S. Marsden, and J. Hay. 1974. Genetic and biochemical studies with herpesvirus. Cold Spring Symp. Quant. Biol. 39:717-730.

38. Wadsworth, S., G. S. Hayward, and B. Roizman. 1976. Anatomy of herpese simplex virus DNA. V. Terminally repetitive sequences. J. Virol. 17:503-512.

39. Wadsworth, S., R. J. Jacob, and B. Roizman. 1975. Anatomy of herpes simplex virus DNA. II. Size, composition, and arrangement of inverted terminal repetitions. J. Virol. 15:1487-1497.

40. Wilkie, N. M. 1976. Physical maps for herpes simplex virus type 1 DNA for restriction endonucleases Hind III, $H p a-1$, and $X$. bad. J. Virol. 20:222-233.

41. Wilkie, N. M., J. B. Clements, J. C. M. Macnab, and J. H. Subak-Sharpe. 1974. The structure and biological properties of herpes simplex virus DNA. Cold Spring Harbor Symp. Quant. Biol. 39:657-666.

42. Wilkie, N. M., and R. Cortini. 1976. Sequence arrangment in herpes simplex virus type 1 DNA: identification of terminal fragments in restriction endonuclease digests and evidence for inversions in redundant and unique sequences. J. Virol. 20:211-221. 